\title{
DEVELOPMENT OF LOW-LEVEL RADIOACTIVE WASTE DISPOSAL CAPACITY IN THE UNITED STATES - PROGRESS OR STALEMATE?*
}

\author{
Jas S. Devgun \\ Office of Waste Management Programs \\ Argonne National Laboratory \\ 9700 S. Cass Ave. \\ Argonne, IL 60439 \\ U.S.A. \\ Gregg S. Larson \\ Midwest Low-Level Radioactive Waste Commission \\ 336 N. Robert St. \\ St. Paul, MN 55101 \\ U.S.A. \\ To be presented at \\ The American Society of Mechanical Engineers \\ Fifth International Conference on Radioactive Waste Management \\ and Environmental Remediation \\ September 3-9, 1995 \\ Berlin, Germany
}

RECEIVED

JAN 3 O 1995

OSTI

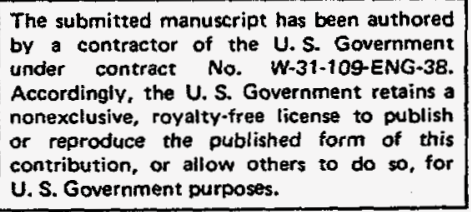

\section{DISCLAIMER}

\begin{abstract}
This report was prepared as an account of work sponsored by an agency of the United States Government. Neither the United States Government nor any agency thereof, nor any of their employees, makes any warranty, express or implied, or assumes any legal liability or responsibility for the accuracy, completeness, or usefulness of any information, apparatus, product, or process disclosed, or represents that its use would not infringe privately owned rights. Reference herein to any specific commercial product, process, or service by trade name, trademark, manufacturer, or otherwise does not necessarily constitute or imply its endorsement, recommendation, or favoring by the United States Government or any agency thereof. The views and opinions of authors expressed herein do not necessarily state or reflect those of the United States Government or any agency thereof.
\end{abstract}

"Work partially supported by the U.S. Department of Energy's Office of Environmental Management, under contract W-31-109-ENG-38. 


\title{
DEVELOPMENT OF LOW-LEVEL RADIOACTIVE WASTE DISPOSAL CAPACITY IN THE UNITED STATES - PROGRESS OR STALEMATE?*
}

\author{
Jas S. Devgun \\ Office of Waste Management Programs \\ Argonne National Laboratory \\ 9700 S. Cass Ave. \\ Argonne, IL 60439 \\ U.S.A. \\ Gregg S. Larson \\ Midwest Low-Level Radioactive Waste Commission \\ 336 N. Robert St. \\ St. Paul, MN 55101 \\ U.S.A.
}

\begin{abstract}
It has been fifteen years since responsibility for the disposal of commercially generated low-level radioactive waste (LLW) was shifted to the states by the United States Congress through the LowLevel Radioactive Waste Policy Act of 1980 (LLRWPA). In December 1985, Congress revisited the issue and enacted the Low-Level Radioactive Waste Policy Amendments Act of 1985 (LLRWPAA). No new disposal sites have opened yet, however, and it is now evident that disposal facility development is more complex, time-consuming, and controversial than originally anticipated. For a nation with a large nuclear power industry, the lack of availability of LLW disposal capacity coupled with a similar lack of high-level radioactive waste disposal capacity could adversely affect the future viability of the nuclear energy option. The U.S. nuclear power industry, with 109 operating reactors, generates about half of the LLW shipped to commercial disposal sites and faces dwindling access to waste disposal sites and escalating waste management costs. The other producers of LLW - industries, government (except the defense related research and production waste), academic institutions, and medical institutions that account for the remaining half of the commercial LLW - face the same storage and cost uncertainties.
\end{abstract}

This paper will summarize the current status of U.S. low-level radioactive waste generation and the status of new disposal facility development efforts by the states. The paper will also examine the factors that have contributed to delays, the most frequently suggested alternatives, and the likelihood of change.

\section{COMMERCIAL WASTE GENERATION AND DISPOSAL STATUS}

For more than twenty years, three disposal facilities (located at Barnwell, South Carolina; Beatty, Nevada; and Richland, Washington) have accepted almost all the commercial LLW generated in the United States. Historically, Barnwell received the bulk of this waste because of its location relative to the states generating the largest amounts of waste.

*Work partially supported by the U.S. Department of Energy's Office of Environmental Management, under contract W-31-109-ENG-38. 
During the last ten years, the total annual volume of commercial LLW disposed at the three facilities has decreased by two-thirds. In 1984, the total volume of waste disposed was approximately $74,200 \mathrm{~m}^{3}$; by 1993 , it had declined to $22,400 \mathrm{~m}^{3}$. However, the total activity of the waste disposed increased dramatically in 1989 and has remained generally high since then. The higher activity may be attributable to the increased age of some nuclear power plants and the need to replace equipment and components with high activity levels. It also may be attributable to LLW generators "cleaning house" of all wastes that could be shipped for disposal before the existing disposal facilities began to restrict access in 1993. Figure 1 summarizes the waste volume and activity changes over the past ten years.

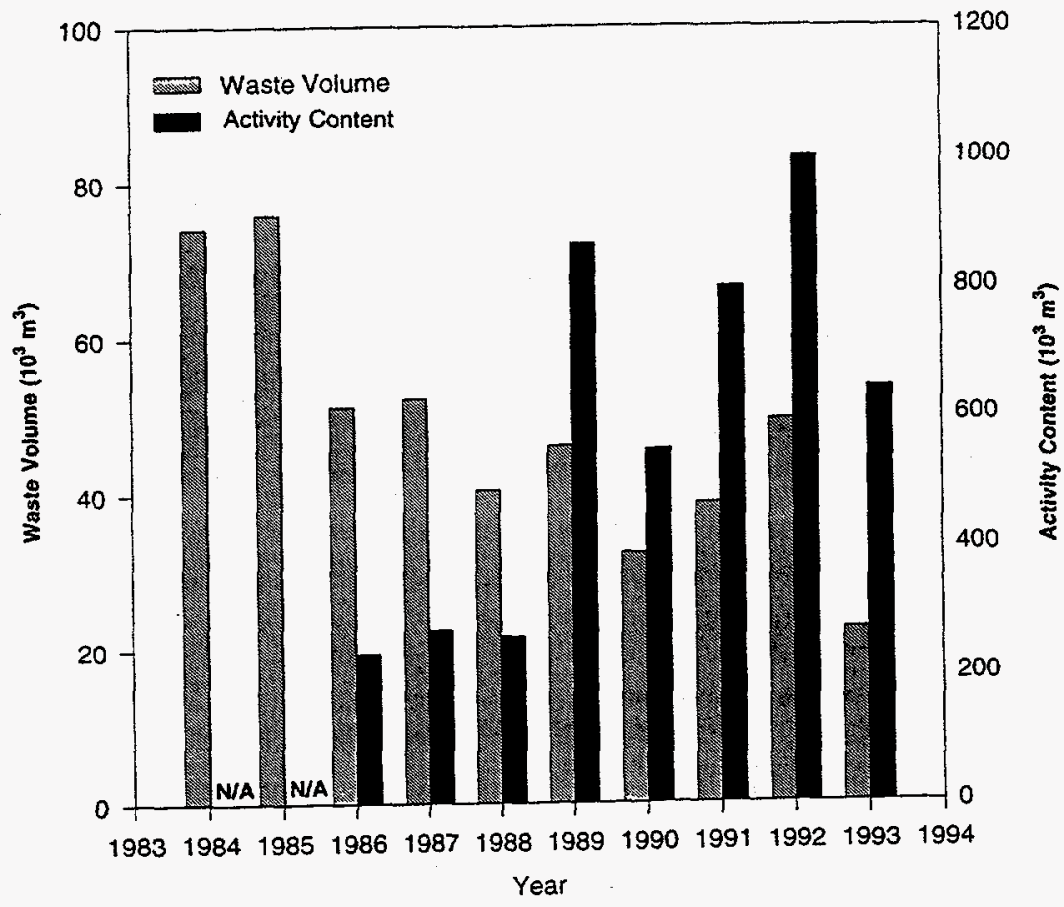

Figure 1. Annual LLW Volume and Activity (N/A Not Available)

As defined in the United States, commercial LLW covers a wide variety of waste types and activity levels. In fact, waste classified as intermediate-level waste under international terminology falls into the category of LLW in the United States. The LLW is divided into four classes based on the concentration of certain short- and long-lived radionuclides. This classification was established by the U.S. Nuclear Regulatory Commission's Licensing Requirements for Land Disposal of Radioactive Waste (10 CFR Part 61) which also sets forth stability requirements. In general, Class A waste, with the lowest concentration of radionuclides, can be disposed of directly without additional stability requirements if it is separated from Class $B$ and Class $C$ waste. Class $B$ and Class $C$ waste forms or containers must maintain their gross physical properties and identity for 300 years. In addition, Class $C$ waste requires disposal at a greater depth than Class $A$ or $B$ waste, or intruder barriers with an effective life of 500 years. Disposal of Greater-thanClass $C$ waste, the LLW with the highest radionuclide concentrations, is a federal responsibility assigned to the U.S. Department of Energy. During the period from 1991 through 1993, Class A waste comprised $95.9 \%$ of the commercial LLW that was shipped for disposal, followed by Class $B$ at $2.7 \%$, and Class $\mathrm{C}$ at $1.4 \%$. 
Among the different sources of commercial LLW, the nuclear power industry generates the largest amount of waste. During the period from 1991 through 1993, the nuclear power industry accounted for $42 \%$ of the waste volume and $89 \%$ of the activity. The LLW (dry active waste and wet solids) generated by nuclear power reactors contains the following key radionuclides: Fe-55, Co-60, Ni-63, Cs-134, Cs-137, Sr-90, I-129, C-14, H-3, Cr-51, Mn-54, and Tc-99. The dry active waste generally consists of contaminated protective clothing, plastics, paper, cloth, adsorbent materials, metals, wood, tools, concrete, and other miscellaneous items. Wet waste consists of resins, filters, evaporator bottoms, and sludges. Wet waste can be dewatered, after which dry waste processing can be applied.

The key radionuclides in the waste originating from industrial sources include: $\mathrm{H}-3, \mathrm{Co}-60, \mathrm{Cs}-$ 137, Cs-134, S-35, P-32, Th-232, Th-230, U-238, Ir-192, and Sr-90. Government-generated waste typically contains Sr-90, Co-60, Fe-55, U-238, Mn-54, Ni-63, Co-58, Ra-226, C-14, H-3, $\mathrm{U}-235, \mathrm{Ni}-59, \mathrm{Tc}-99, \mathrm{Am}-241, \mathrm{I}-125$, and $\mathrm{Cs}-137$. The academic waste generally contains $\mathrm{H}-3$, Co-60, l-129, Pm-147, S-35, Cr-51, P-32, C-14, l-131, I-125, Ca-45, Ni-63, Ra-226, Co-57, and $\mathrm{K}-40$, while the medical waste may include P-32, C-14, S-35, Co-57, Ba-133, I-125, Ca-45, Cr-51, Tc-99m, and $\mathrm{H}-3$.

Most of the activity in commercial LLW comes from short-lived radionuclides. A 1993 U.S. Nuclear Regulatory Commission study found that during 1987, 1988, and $1989,96 \%$ of the activity disposed at Barnwell, $99 \%$ of the activity disposed at Beatty, and $98 \%$ of the activity disposed at Richland consisted of isotopes with a half-life of $\mathbf{3 0}$ years or less. Moreover, at least $80 \%$ of the activity disposed at each of the sites was attributable to three radionuclides: Fe-55 (2.7 year half-life), Co-60 (5.3 year half-life), and $\mathrm{H}-3$ (12.3 year half-life).

During the period from 1991 through 1993, the states shipping the largest volumes of LLW for disposal were Illinois, Pennsylvania, Oregon, Virginia, and Tennessee. Based on the total activity content of the waste shipped, the largest contributing states were Pennsylvania, Georgia, New York, Alabama, and Illinois.

\section{STATES, REGIONAL COMPACTS, AND NEW DISPOSAL CAPACITY DEVELOPMENT}

\section{Legislative Drivers}

When Congress assigned LLW disposal responsibility to the states in the LLRWPA of 1980, it encouraged the states to form regional compacts rather than develop their own, individual disposal facilities. To encourage the states to form compacts, Congress gave them the legal authority to exclude any waste generated outside of their compact regions. States acting independently lacked a similar exclusionary authority.

Assuming that new disposal facilities could be operating by January 1, 1986, the 1980 legislation provided that after January 1, 1986, compacts could restrict the use of their disposal facilities by excluding waste generated outside their member states. By 1983, however, it had become clear that no new disposal facilities would be operational by the 1986 milestone because of the time required by the states to negotiate compact agreements and obtain the necessary consent of Congress to the compacts. As a result, the LLRWPAA was passed by Congress in December, 1985, at the same time when Congress granted consent to the original seven compacts comprising 35 states (Central, Central Midwest, Midwest, Northeast, Northwest, Rocky Mountain, and Southeast Compacts). The LLRWPAA extended the January 1, 1986, deadline by seven 
years, to January 1,1993 , and established a series of milestones, penalties, and incentives to encourage the compacts and states to develop new disposal capacity by the 1993 deadline.

\section{Current Status}

It is now 1995 and no new disposal facilities have opened, although four compacts have selected sites and submitted license applications. As provided for in the LLRWPAA, on January 1, 1993, the Beatty disposal facility permanently closed, and access to the Richland facility was restricted to the 11 states in the Northwest Compact and the Rocky Mountain Compact. On July 1, 1994, access to the Barnwell facility was restricted to the eight states in the Southeast Compact.

As of December 1994, ten compacts had been established comprising 45 states (see Figure 2). The ten include three new compacts (Appalachian, Southwestern, and Texas Compacts) formed since Congress granted consent to the original seven in 1985. Massachusetts, Michigan, New York, New Hampshire, Rhode Island, the District of Columbia, and Puerto Rico remain unaffiliated. Michigan was a member of the Midwest Compact, but its membership was revoked in 1991 when it failed to develop a regional disposal facility. Michigan generators also were denied access to the disposal facilities and have stored their waste on-site since November 1990.

The compacts are at various stages in providing or developing disposal capacity. Table 1 gives a snapshot view of the status of the compacts as of June 1994. Two compacts (Northwest and Rocky Mountain) will continue to use the existing facility at Richland, Washington. The Southeast Compact also is currently served by the existing facility at Barnwell, South Carolina, but a license application has been submitted for a new regional disposal facility in North Carolina. The Southwestern Compact has been granted a license for a new regional disposal facility in California, but it has encountered litigation and land acquisition problems. The Central and Texas Compacts have selected sites in Nebraska and Texas respectively, and submitted license applications. The Appalachian Compact is nearing the final stage of its siting process in Pennsylvania. Three remaining compacts (Central Midwest, Midwest, and Northeast) either have encountered setbacks and started over, or have not advanced. In the unaligned states, Massachusetts and New York have enacted legislation and have established siting processes. No activities are underway in the other unaffiliated states, the District of Columbia, or Puerto Rico.

\section{Progress or Stalemate? An Analysis}

Cumbersome site selection processes, and public and political opposition to those processes, have generally been the biggest impediments to progress in developing new disposal facilities. Other factors have included issues related to funding, enabling legislation, liability, risk, and disposal technology. Even the states that had aggressive siting plans have encountered delays, and legislative milestones have slipped. For example, in the Central Midwest Compact, a volunteer site at Martinsville, Illinois, was proposed for licensing by the state's Department of Nuclear Safety. The site, however, was rejected by a state siting commission after several years of site characterization activities and over $\$ 75$ million in expenditures. As a result, the state legislature enacted new procedures for siting a disposal facility, and the initial plan to operate a facility in 1995 has been discarded. The only new facility which currently appears close to construction is the Southwestern Compact's proposed site at Ward Valley, California. Again, however, litigation and the federal government's decision to suspend action on the transfer of federal land for the California site has presently stalled construction. 


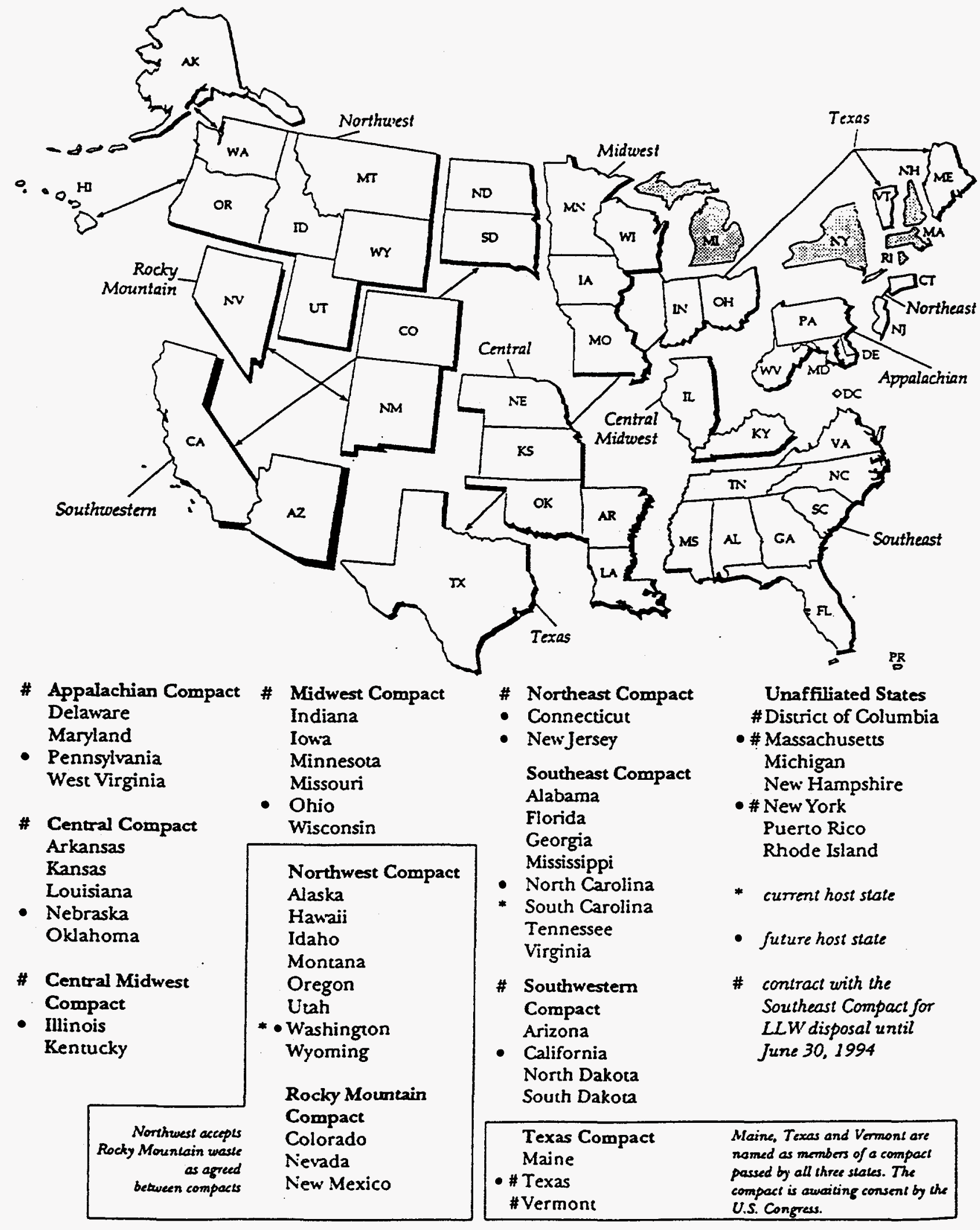

Figure 2. State Compacts

(Source: LLW Forum Summary Report, Vol 2, No. 2, June 94 by Afton Associates, Inc.) 
TABLE I. Status of Compact/State Disposal Facility Development

\begin{tabular}{|c|c|c|c|c|c|}
\hline $\begin{array}{l}\text { Compact or } \\
\text { Unaffiliated } \\
\text { State }\end{array}$ & Host State & Disposal Technology & $\begin{array}{l}\text { License } \\
\text { Application } \\
\text { Submittal }\end{array}$ & $\begin{array}{l}\text { Estimated } \\
\text { Development } \\
\text { Cost }\end{array}$ & $\begin{array}{l}\text { Expected } \\
\text { Operation }\end{array}$ \\
\hline $\begin{array}{l}\text { Appalachian } \\
\text { Compact }\end{array}$ & Pennsylvania & Earth-mounded above-ground vault & Early 1997 & $\$ 66 \mathrm{M}$ & Mid-1999 \\
\hline $\begin{array}{l}\text { Central } \\
\text { Compact }\end{array}$ & Nebraska & Above-ground vault & $\begin{array}{l}\text { Submitted } \\
\text { July } 1990\end{array}$ & $\$ 139.8 \mathrm{M}$ & Sept. 1998 \\
\hline $\begin{array}{l}\text { Central Midwest } \\
\text { Compact }\end{array}$ & Illinois & Above-grade, earthen-covered concrete vault & Nov. 1997 & Not available & July 2000 \\
\hline $\begin{array}{l}\text { Midwest } \\
\text { Compact }\end{array}$ & Ohio & None selected at this time & $\begin{array}{l}\text { By } 41 / 4 \text { yrs. } \\
\text { after Ohio } \\
\text { enacts } \\
\text { legislation }\end{array}$ & Not available & $\begin{array}{l}\text { By } 71 / 4 \text { yrs. } \\
\text { after Ohio } \\
\text { enacts } \\
\text { legislation }\end{array}$ \\
\hline \multirow[t]{2}{*}{$\begin{array}{l}\text { Northeast } \\
\text { Compact }\end{array}$} & New Jersey & $\begin{array}{l}\text { Shallow land burial prohibited. Technology will } \\
\text { depend on preference of volunteer community, } \\
\text { site-specific requirements, and the technology } \\
\text { licensing requirements. }\end{array}$ & July 1997 & $\$ 100 \mathrm{M}$ & Late 1999 \\
\hline & Connecticut & $\begin{array}{l}\text { Shallow land burial prohibited. A state Board will } \\
\text { select the technology in consultation with the } \\
\text { volunteer community. }\end{array}$ & July 1997 & $\$ 100 M$ & Dec. 1999 \\
\hline $\begin{array}{l}\text { Northwest } \\
\text { Compact }\end{array}$ & Washington & $\begin{array}{l}\text { Shallow land burial } \\
\text { Existing facility at Richland, WA. }\end{array}$ & Not applicable & Not applicable & $\begin{array}{l}\text { Currently } \\
\text { operating }\end{array}$ \\
\hline $\begin{array}{l}\text { Rocky Mountain } \\
\text { Compact }\end{array}$ & Not applicable & $\begin{array}{l}\text { Not applicable } \\
\text { Has negotiated access to Richland, WA facility. }\end{array}$ & Not applicable & Not applicable & $\begin{array}{l}\text { Not } \\
\text { applicable }\end{array}$ \\
\hline \multirow[t]{2}{*}{$\begin{array}{l}\text { Southeast } \\
\text { Compact }\end{array}$} & $\begin{array}{l}\text { South Carolina } \\
\text { (Current) }\end{array}$ & Shallow land burial & Not applicable & Not applicable & $\begin{array}{l}\text { Currently } \\
\text { operating }\end{array}$ \\
\hline & $\begin{array}{l}\text { North Carolina } \\
\text { (Designated) }\end{array}$ & Integrated vault & $\begin{array}{l}\text { Submitted } \\
\text { Dec } 1993\end{array}$ & $\$ 155 M$ & Mid-1997 \\
\hline $\begin{array}{l}\text { Southwestern } \\
\text { Compact }\end{array}$ & California & Enhanced shallow land burial & $\begin{array}{l}\text { Issued } \\
\text { Sept } 1993\end{array}$ & $\$ 75 M$ & Mid-1997 \\
\hline $\begin{array}{l}\text { Texas Compact } \\
\text { (Pending) }\end{array}$ & Texas & Below-ground concrete canisters & $\begin{array}{l}\text { Submitted } \\
\text { Dec } 1993\end{array}$ & $\$ 60 \mathrm{M}$ & Mid-1997 \\
\hline Massachusetts & Not applicable & $\begin{array}{l}\text { Shallow land burial prohibited. Technology will } \\
\text { be chosen by the local community from methods } \\
\text { certified by the LLW Management Board. }\end{array}$ & Jan./Feb. 1998 & Not available & $2000 / 2001$ \\
\hline Michigan & Not applicable & $\begin{array}{l}\text { Michigan law limits technology to above- or below- } \\
\text { ground concrete vaults or canisters. No final } \\
\text { decision has been made on facility design. }\end{array}$ & Not available. & Not available & Not available \\
\hline New York & Not applicable & $\begin{array}{l}\text { State law bars shallow land burial. No disposal } \\
\text { technology has been selected as yet. }\end{array}$ & June 1999 & Not available & Not available \\
\hline New Hampshire & Not applicable & Not planning to site a facility & Not applicable & Not applicable & $\begin{array}{l}\text { Not } \\
\text { applicable }\end{array}$ \\
\hline Rhode Island & Not applicable & Not planning to site a facility & Not applicable & Not applicable & $\begin{array}{l}\text { Not } \\
\text { applicable }\end{array}$ \\
\hline $\begin{array}{l}\text { District of } \\
\text { Columbia }\end{array}$ & Not applicable & Not planning to site a facility & Not applicable & Not applicable & $\begin{array}{l}\text { Not } \\
\text { applicable }\end{array}$ \\
\hline Puerto Rico & Not applicable & Not planning to site a facility & Not applicable & Not applicable & $\begin{array}{l}\text { Not } \\
\text { applicable }\end{array}$ \\
\hline
\end{tabular}




\section{Past Experience and Future Designs}

The problems experienced at older disposal sites that have been closed for many years (Maxey Flats, Kentucky; West Valley, New York; and Sheffield, Illinois) have contributed to public distrust of siting processes and the lack of acceptance of waste disposal facilities. Generally, problems at these sites can be traced to inadequate site characterization and the lack of an integrated systems approach to waste management and disposal.

The shallow land burial concept, as practiced in the past, has been rejected by states and compacts developing new disposal facilities. Only California (Southwestern Compact) will use a shallow land burial design at its desert site, but in a technologically enhanced form. Most disposal facility designs now under consideration incorporate concrete intruder barriers and other engineered features. These engineered features delay radionuclide migration and supplement the natural barriers characteristic of a suitable site. The design concepts have generally focused on concrete canisters or concrete vaults, or a combination of both, under an earthen cover. These designs are similar to those that have already been successfully employed in Canada and some European countries.

With a preference for engineered structures, the states and compacts have moved away from the land disposal approach that served as the basis for the U.S. Nuclear Regulatory Commission's 10 CFR Part 61 licensing rule. While revisions to 10 CFR Part 61 may not be necessary, a more specific, case-by-case approach to performance assessment and licensing is required.

\section{Key Questions and Discussion}

- $\quad$ Are the compacts stalled in their progress?

Although the first legislation was passed in 1980 , compacts did not really proceed with site development activities until 1986, after Congress had formally consented to the new compacts. The siting process has proved to be more complex, time-consuming, and controversial than originally anticipated. However, significant progress has been made, for example, when compared to the high-level radioactive waste disposal program in the United States. Also, progress is significant when compared with development of new (not expanded) hazardous waste disposal sites in the United States during the same time period. Given that in the United States, any type of waste disposal, even municipal solid waste disposal, is an increasingly intractable problem, the delays in developing LLW disposal facilities are understandable.

- What is the impact of waste minimization?

Steep increases in disposal costs and the dwindling access to disposal sites have necessitated implementation of source reduction strategies and extensive use of volume reduction technologies. A good example is the nuclear power industry. Concerted efforts by the utilities in source reduction and volume reduction have led to average volumes of dry active waste (which accounts for 60 to $70 \%$ of waste generated by a reactor) that are about one-fifth of the volumes produced only a decade ago. By 1992, an average pressurized water reactor (PWR) generated about $57 \mathrm{~m}^{3}$ of LLW annually, and a boiling water reactor (BWR) about $142 \mathrm{~m}^{3}$ annually. Similarly, because of the increasing treatment of wet waste, the annual average volume of wet reactor waste has declined to about $28 \mathrm{~m}^{3}$ for a PWR and about $113 \mathrm{~m}^{3}$ for a BWR. 
Compaction and supercompaction are the most widely used techniques to reduce volume of compactable solid waste. Table II lists various technologies that can be applied to solid, wet solid, and liquid wastes. In addition, the higher activity waste can be stabilized through bituminization, cementation, or vitrification.

Table II. Volume Reduction Technologies

\begin{tabular}{|l|l|l|}
\hline \multicolumn{1}{|c|}{ Solid Waste } & \multicolumn{1}{c|}{ Liquid Waste } & \multicolumn{1}{c|}{ Wet Solids } \\
\hline Compaction & Evaporation & Sedimentation \\
Supercompaction & Distillation & Drying \\
Baling & Crystallization & Dewatering \\
Shredding & Precipitation & Dehydration \\
Incineration & Centrifugation & Incineration \\
& Filtration/Ultrafiltration & \\
& Sedimentation & \\
& lon-Exchange & \\
& Reverse Osmosis & \\
\hline
\end{tabular}

As is evident in Figure 1, while the waste volumes have been drastically reduced over the past decade, the activity content of the waste has remained unchanged. The drop in volumes, however, has raised questions about the need for the same level of disposal capacity development as originally anticipated.

- $\quad$ Are too many sites being developed?

There is no technical obstacle to disposing of all LLW in the United States at one location. However, there appears to be no political will or way to build one site to serve all of the states because of equity arguments. While three sites served the country for more than twenty years, internal political opposition in those states led to a determination that a greater distribution of the burden was necessary.

- What alternatives to the existing framework would speed development of new disposal capacity?

The alternatives to the current framework that are most frequently suggested are (1) federalizing the process or (2) privatizing the process. On a closer examination, however, it becomes clear that these alternatives do not offer the promise of more timely development. For one thing, starting over would sacrifice all of the progress made to date and would contribute to further delay. Furthermore, none of the alternatives are immune from the characteristics that have delayed current progress: political lack of will, regulatory change over time, litigation, media hype, anti-nuclear advocates, and public opposition will continue to affect waste management efforts regardless of the organizational framework. Finally, local community sentiment, often described as "not in my backyard" opposition, has been a significant impediment and will not disappear.

Theoretically, there are a number of things that could help advance the process. These include the following: streamlining the siting and licensing processes; establishing new milestones, incentives and penalties; educating the public, providing technical assistance, and cultivating trust; and reducing opportunities for litigation. Many of these actions, however, may be 
impractical or politically impossible to achieve.

- What is the likelihood of change?

At the moment, the prospects for change are not good. The U.S. Congress assigned this responsibility to the states at their urging, and the Congress is unlikely to reopen the issue of regional compacts. The federal government has had its own setbacks with the high-level waste repository siting and the Department of Energy's waste management and site restoration programs. In addition, the states that are well along in the development of new disposal facilities, or already have disposal facilities, are leery of change because such change could adversely affect them.

A continued lack of LLW disposal capacity, coupled with a similar lack of high-level waste disposal capacity, could adversely affect the future of nuclear power. This fact is recognized by some anti-nuclear advocates, and mid-course changes to the process or further delays could advance their agendas. On the other hand, some generators are frustrated with the escalating costs of disposal, as well as the outright denial of access to disposal, and the resulting need to store waste on-site. Politicians whose constituents are near proposed disposal sites or on-site storage locations have their own interests to consider.

Overall, it appears that most states, national generator organizations, professional groups, and Congress support the current arrangement. The process is moving ahead, but at a slower pace than originally anticipated.

\section{- What about storage?}

The LLW generators in 29 states currently have no access to a disposal facility. On-site, interim storage is the only available option until a disposal facility in their compact or state opens for operation.

At nuclear power plant sites, the LLW is generally stored in specially engineered buildings. For example, the Cook Plant in Bridgeman, Michigan, has relied on such a structure for storing waste on-site since November 1990, when the waste generators in the state of Michigan lost access to existing disposal facilities. The dry active waste can be stored in stackable metal boxes, wood containers, or 55-gallon drums. For the dewatered resins and filters, the current standard practice involves interim storage in high-integrity containers (HICs). Solidification of such waste with materials such as cement is another option. Internationally, a variety of structures are used for long-term storage of higher-activity waste. These include concrete trenches, cylindrical bunkers, concrete monoliths/radblocks, in-ground storage containers (ISCs), dry storage modules (DSMs), tile holes, and quadricells.

Although the nuclear power plants are generally well-prepared for on-site storage, the smaller industrial, medical, and academic generators do not all have the space, financial resources, and waste management personnel that may be necessary for such storage. These generators, therefore, may experience the greatest difficulties with on-site storage, and they may be the first to curtail activities involving the use of radioactive materials.

On-site storage is an interim option that is necessitated by the lack of available disposal capacity. 
While on-site storage historically has been used for the decay (to innocuous levels) of certain types of LLW containing only radionuclides with very short half-lives, it is not applicable to the bulk of the LLW. This current situation is helping to refocus national attention on LLW disposal needs and may result in some actions at the state level to facilitate progress in the development of disposal facilities. It forces opponents to justify their opposition to a carefully sited and designed centralized disposal facility, managed by waste professionals, when the alternative is on-site temporary storage at numerous locations that were not selected for their environmental characteristics and where operators may lack waste management expertise. Ultimately, the waste will need disposal.

\section{CONCLUSION}

It is clear that the time frames established in the LLRWPA and LLRWPAA were not sufficient. While the formation of regional compacts represents a significant accomplishment, and progress has been made in developing new disposal capacity, the process has proven to be very complex, time-consuming, and contentious. A number of factors have contributed to the delays, especially the prevailing public attitude of "not in my backyard."

The last disposal facility that accepted the bulk of the LLW in the United States closed it's doors to out-of-compact waste as of July 1,1994. With dwindling access to commercial facilities in the country, the nuclear power plants and other generators of LLW are forced to store waste on-site. The LLW generators have done an excellent job in waste minimization through source reduction, application of volume reduction technologies, and in implementing interim on-site storage. However, such storage is temporary action, and further disposal capacity in the United States must be developed.

\section{BIBLIOGRAPHY}

"1993 State-By-State Assessment of Low-Level Radioactive Wastes Received at Commercial Disposal Sites," Idaho National Engineering Laboratory, EG\&G Idaho, Inc., National Low-Level Waste Management Program, DOE/LLW-205, September 1994; and previous reports in this series.

"Radwaste Generation Survey Update, Volume 1: Boiling Water Reactors; Volume 2: Pressurized Water Reactors," Electric Power Research Institute report EPRI NP-5526, February 1988.

"Source Term Evaluation for Radioactive Low-Level Waste Disposal Performance Assessment," U.S. Nuclear Regulatory Commission, NUREG/CR-591, January 1993.

"Summary Report," Low-Level Radioactive Waste Forum, Volume 2, Number 2, by Afton Associates, Inc., Washington, DC, June 1994.

"Licensing Requirements for Land Disposal of Radioactive Waste" U.S. Nuclear Regulatory Commission, Title 10, Code of Federal Regulations, Part 61, December 1982. 